\title{
Research on complex enzyme system to extract Hibiscus Sabdariffa $L$ reducing sugar
}

\author{
Hua LIU ${ }^{1,2 *}$ (D), Wei CHEN ${ }^{1}$, Rui-Ting LI $^{1}$
}

\begin{abstract}
Hibiscus Sabdariffa L. has important nutritional and medicinal value. Currently, a safe process extraction of reducing sugar from Hibiscus Sabdariffa L. calyx by biological complex enzyme system is seldom investigated. In this experiment, the pectinase and cellulase complex enzyme system was used to optimize the enzymatic hydrolysis of Hibiscus Sabdariffa L. and Box behnken was used to design the experiment. The results showed that there was significant difference in enzymolysis effect of Hibiscus Sabdariffa $L$ under different conditions $(\mathrm{p}<0.05)$. When the enzymolysis temperature was $45^{\circ} \mathrm{C}, \mathrm{pH} 4.5$, and the mass volume ratio of material to liquid was $5 \mathrm{~g}: 100 \mathrm{ml}$, the optimum conditions were obtained by response surface methodology: the addition amount of pectinase and cellulase complex enzyme was $0.011 \mathrm{~g} / \mathrm{kg}$, the ratio of mixed enzyme was 1.36:1, the enzymolysis time was $2.09 \mathrm{~h}$, and the reducing sugar content of Hibiscus Sabdariffa L extract was $3.56 \mathrm{mg} / \mathrm{ml}$. The experimental results of reducing sugar content of Hibiscus Sabdariffa L $(3.54 \pm 0.1 \mathrm{mg} / \mathrm{ml})$ were in good agreement with the predicted value of the equation fitted by response surface. The mixed enzyme system of pectinase and cellulase has the advantages of environmental protection and energy saving, which can provide guidance for industrial production.
\end{abstract}

Keywords: Hibiscus Sabdariffa L; cellulase; pectinase; enzymolysis; response surface; methodology.

Practical Application: Efficient extraction of reducing sugars by multiple enzyme systems.

\section{Introduction}

Hibiscus sabdariffa L., also known as kaketti, luoshenhua, luoshenkui, shanqie, etc., is an annual shrub of Malvaceae wood mold genus, which is produced in Africa and has been planted for hundreds of years. Now it is widely distributed in tropical and subtropical regions of the world and is a tropical and subtropical economic crop with a variety of economic uses. The plant of Hibiscus Sabdariffa is 1.5 to $2 \mathrm{~m}$ high. The stem is light purple, erect, with many branches and alternate leaves. Hibiscus Sabdariffa blooms in summer and autumn, with long flowering period, cup-shaped calyx, purplish red, yellow corolla, good ornamental, and has the reputation of "plant ruby". Hibiscus Sabdariffa is not only a ornamental plant, but also has important nutritional health care and medicinal value. Calyx, seed, leaf and stem can be used. The unique nutritional value, healthcare and medicinal value of Hibiscus Sabdariffa determine that Hibiscus Sabdariffa has broad development and application prospects (Dhar et al., 2015). Hibiscus Sabdariffa has been used as food raw materials or medicinal healthcare ingredients in my countries (Riaz \& Chopra, 2018). It is of great significance to develop Hibiscus Sabdariffa related products through multi-channel, and speed up the way of industrialization development to promote the usage of the active component of Hibiscus Sabdariffa and increase its economic values through deep processing (Salem et al., 2021). The calyx of Hibiscus Sabdariffa is purplish red, which contains a lot of organic acids such as citric acid, hibiscic acid, reducing sugar, vitamin $\mathrm{C}$, protein, natural pigment and minerals (Zhen et al., 2016). Some studies on the chemical constituents and pharmacological effects of Hibiscus Sabdariffa calyx show that Hibiscus Sabdariffa calyx has antioxidant, anti-tumor (Arenas et al., 2016), cardiovascular protection (Carvajal-Zarrabal et al., 2012), liver protection, antihypertensive (Dhar et al., 2015), diuretic and antilithiasis effect (Chen et al., 2020a).

A lot of researches have been done on the extraction, structure analysis and health tea production of natural pigment from Hibiscus Sabdariffa calyx. The common extraction methods of plant ingredients at home and abroad include solvent extraction, pressure bath extraction, microwave-assisted extraction, ultrasonic assisted extraction and so on. These methods are usually mixed with organic solvents, which affect the natural and safety of food. In the extraction of active components from plant samples, the use of biological enzymes can soften and decompose the cell wall, reduce the resistance of pigment extraction and bioactive substances, change the binding mode between the internal molecules of substances, and promote the release of effective components, so as to extract effective components efficiently and quickly. Due to the specificity of enzyme, the content of active substance can be increased by using biological enzyme method. Enzymatic hydrolysis has become one of the most effective and promising technologies in the field of green deep processing (Uddin Pk et al., 2019). Reducing sugars are reducing sugars. Monosaccharides containing free aldehyde or ketone groups and disaccharides containing free aldehyde groups are both reducing sugars. Reducing sugars include glucose, fructose, galactose, lactose, maltose, etc. As an important effective component of 
Hibiscus Sabdariffa calyx, reducing sugar can be used as an index to reflect the enzymatic hydrolysis effect of Hibiscus Sabdariffa calyx under different enzymatic hydrolysis conditions.

At present, the application of Hibiscus Sabdariffa research, biological enzymatic hydrolysis technology is rarely involved. In this study, under the conditions of a certain enzymatic reaction temperature and initial $\mathrm{pH}$ value, the effects of the amount of pectinase and cellulase compound enzyme, the proportion of compound enzyme and the enzymatic hydrolysis time on the reducing sugar concentration of Hibiscus Sabdariffa enzymatic hydrolysate were studied. The optimal enzymatic hydrolysis process was obtained by response surface analysis. The application of pectinase and cellulase compound enzyme system in Hibiscus Sabdariffa enzymatic hydrolysis process not only improved the quality of Hibiscus Sabdariffa. The extraction rate of Hibiscus Sabdariffa can also reduce the cost of Hibiscus Sabdariffa processing and extraction, which can well replace the imported plant hydrolase, and provide scientific experimental basis for the rational and full use of Hibiscus Sabdariffa resources.

\section{Materials and methods}

\subsection{Materials}

HibiscuS Sabdariffa $L$ is collected from a local planting farm and preserved in authors' laboratory (cold storage). Cellulase (enzyme activity $1500 \mathrm{NCU} / \mathrm{g}$, optimal temperature $50{ }^{\circ} \mathrm{C}$, $\mathrm{pH} 4.5)$ and pectinase $\left(50^{\circ} \mathrm{C}\right.$ and $\left.\mathrm{pH} 4.5\right)$ were purchased from novozyme Biotechnology Co., Ltd. Glucose standard solution $(5.00 \mathrm{mg} / \mathrm{ml})$ was prepared by accurately weighing $5.000 \mathrm{~g}$ of glucose powder dried at $121{ }^{\circ} \mathrm{C}$, and fixing the volume to $1000 \mathrm{ml}$ with distilled water. Anhydrous ethanol, phenol and other chemical reagents are analytical pure.

\subsection{Sample pretreatment}

The Hibiscus Sabdariffa was washed with water and seeded. The calyx was dried at $55{ }^{\circ} \mathrm{C}$ for $10 \mathrm{~h}$, crushed, screened through 70 mesh sieve, and sealed. $5 \mathrm{mg}$ Hibiscus Sabdariffa L calyx powder is weighed, added with $100 \mathrm{ml}$ distilled water, adjusted to the optimum $\mathrm{pH}$ value with $0.1 \mathrm{~mol} / \mathrm{l}$ sodium hydroxide or hydrochloric acid solution, adding corresponding enzymes, enzymolysis in a constant temperature water bath at a predetermined temperature, controlling the $\mathrm{pH}$ value of the reaction system. After the enzymolysis time is reached, the enzyme is inactivated in boiling water bath for $10 \mathrm{~min}$, cooled, centrifuged at $4000 \mathrm{R} / \mathrm{min}$ for $15 \mathrm{~min}$, and the supernatant is determined at constant volume.

The Hibiscus Sabdariffa enzymatic hydrolysate was put into the extraction container. After the extract was filtered and concentrated, 95\% ethanol was added to freeze centrifugation for $15 \mathrm{~min}$. the precipitate was collected to obtain the mixture of Hibiscus Sabdariffa polysaccharide and protein. The mixture was dissolved in distilled water, decolorized by activated carbon, deproteinized with Sevage reagent (n-butanol: chloroform $=4: 1$ ) for several times. Finally, the supernatant was constant volume and shaken to obtain the Hibiscus Sabdariffa polysaccharide extract (Figure 1).

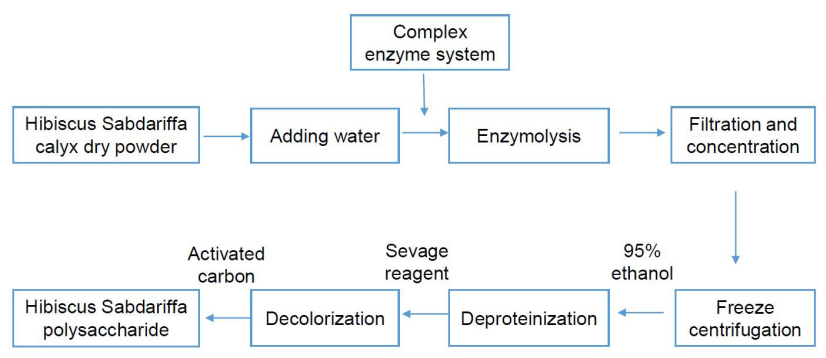

Figure 1. Enzymatic extraction process of Hibiscus Sabdariffa reducing sugar. Put the Hibiscus sabdariffa enzymolysis extract into the extraction container, filter and concentrate the extract, add 95\% ethanol, freeze and centrifuge for $15 \mathrm{~min}$, collect and precipitate to get the Hibiscus sabdariffa polysaccharide and protein mixture, dissolve it with distilled water, decolorize it with activated carbon, deproteinize it with Sevage reagent several times, finally fix the volume of the supernatant and shake it up to get Hibiscus sabdariffa polysaccharide extract.

\subsection{Determination of reducing sugar content and light transmittance}

Preparation of developer and solution

After the above reaction, the sample was taken out and cooled to room temperature, and the filtrate was extracted by vacuum pump (predilution is required for high concentration), add the pre prepared color reagent, heat it in boiling water bath, take it out and cool it with tap water, then add distilled water and mix well. Under the wavelength of $540 \mathrm{~nm}$, measure the absorbance of the sample with a colorimetric dish and calculate the content of reducing sugar according to the corresponding standard curve. The formula for calculating the mass percentage of reducing sugar in the sample is as follows: Mass percent of reducing sugar $(\%)=($ reducing sugar $\mathrm{mg} / \mathrm{ml} \times$ sample solution volume $\mathrm{ml}$ ) / sample mass $\mathrm{mg} \times 100 \%$, in which $\mathrm{X}$ is the content of reducing sugar in the sample (based on glucose, \%); C is the concentration of glucose standard solution $(\mathrm{mg} / \mathrm{ml}) ; \mathrm{M}$ is the mass of sample (g); $\mathrm{V}$ is the constant volume of the sample ( $\mathrm{ml}$ ); $\mathrm{V} 1$ is the volume $(\mathrm{ml})$ of glucose standard solution consumed by titrating $10 \mathrm{ml}$ of Fehling's solution $(5 \mathrm{ml}$ of solution a and $5 \mathrm{ml}$ of solution b); $\mathrm{V} 2$ is the average volume of sample solution consumed in the determination $(\mathrm{ml})$.

\section{Preparation of 3,5-Dinitrosalicylic acid reagent}

Dissolved a total of $182 \mathrm{~g}$ of potassium sodium tartrate in $500 \mathrm{ml}$ water to prepare potassium sodium tartrate hot solution. $6.3 \mathrm{~g}$ of 3,5-Dinitrosalicylic acid was weighed, $262 \mathrm{ml}$ of $2 \mathrm{~mol} / \mathrm{L}$ $\mathrm{NaOH}$ was added to the hot solution of potassium sodium tartrate, then $5 \mathrm{~g}$ of crystalline phenol and $5 \mathrm{~g}$ of sodium bisulfite were added, stirred and dissolved (Archaina et al., 2019). After cooling, the volume was fixed to $1000 \mathrm{ml}$ and stored in a brown bottle for standby.

\section{The production of standard curve}

We accurately weighed $100 \mathrm{mg}$ of glucose standard dried at $105^{\circ} \mathrm{C}$ to constant weight, add a small amount of distilled water to dissolve, and fix the volume to $100 \mathrm{ml}$ to obtain the reference solution containing $1 \mathrm{mg} / \mathrm{ml}$ glucose for standby 
(Li et al., 2019). Then we take different volumes of $0.1 \%$ glucose standard solution and standard glucose solution, fix the volume to $50 \mathrm{ml}$, take the tube with plug, and add $2.5 \mathrm{ml}$ of the above solutions in turn, then add $2.5 \mathrm{ml}$ of 3,5-Dinitrosalicylic acid chromogenic solution in each tube, and shake well and boil for 5 min, taking another blank as control. After cooling, the model 721 spectrophotometer was used to zero with a blank control tube at $540 \mathrm{~nm}$ wavelength, and the OD value was determined. Each group of experiments was repeated three times. The standard curve of glucose was drawn with the optical density value as the abscissa and the glucose content (mg) as the ordinate.

\section{Determination of light transmittance}

The Hibiscus Sabdariffa polysaccharide extract was added to the cuvette and compared with distilled water. At the wavelength of $540 \mathrm{~nm}$, the transmittance of the sample was measured and expressed as $\mathrm{t}(\%)$.

\subsection{Single factor experiment of enzymatic hydrolysis}

Effect of pectinase addition on enzymatic hydrolysis of Hibiscus Sabdariffa was determined as follows, under the conditions of $50{ }^{\circ} \mathrm{C}, \mathrm{pH} 4.5$, hydrolysis time $2 \mathrm{~h}$, the effects of cellulase (Zhou et al., 2020) and pectinase (Magro et al., 2018) complex enzyme dosage of $0 \mu \mathrm{L}, 20 \mu \mathrm{L}, 30 \mu \mathrm{L}, 40 \mu \mathrm{L}, 50 \mu \mathrm{L}$ (the enzyme amount is based on the quality of raw materials, the same below) on the extraction of reducing sugar and light transmittance of Hibiscus Sabdariffa were studied (Zhao \& Dong, 2016).

Effect of cellulase addition on enzymatic hydrolysis of Hibiscus Sabdariffa was determined as follows, under the conditions of $50^{\circ} \mathrm{C}, \mathrm{pH} 4.5$, enzymatic hydrolysis time $2 \mathrm{~h}$, the effects of cellulase and pectinase complex enzyme dosage of $0 \mu \mathrm{L}, 20 \mu \mathrm{L}, 30 \mu \mathrm{L}, 40 \mu \mathrm{L}, 50 \mu \mathrm{L}$ on the extraction of reducing sugars and transmittance of Hibiscus Sabdariffa were studied (Magro et al., 2019).

Eeffect of the addition of cellulase and pectinase on the enzymatic hydrolysis of Hibiscus Sabdariffa was determined as follows, under the conditions of $50^{\circ} \mathrm{C}, \mathrm{pH} 4.5$, hydrolysis time $2 \mathrm{~h}$, the effects of cellulase and pectinase complex enzyme dosage of $0 \mu \mathrm{L}, 20 \mu \mathrm{L}, 30 \mu \mathrm{L}, 40 \mu \mathrm{L}, 50 \mu \mathrm{L}$ (the enzyme amount is based on the quality of raw materials, the same below) on the extraction rate and transmittance of Hibiscus Sabdariffa reducing sugar were studied.

Effect of the ratio of cellulase to pectinase on enzymatic hydrolysis of Hibiscus Sabdariffawas determined as follows, under the conditions of enzymolysis temperature $50^{\circ} \mathrm{C}, \mathrm{pH} 4.5$, enzymolysis time $2 \mathrm{~h}$, the effects of cellulase and pectinase complex enzyme addition amount of $40 \mu \mathrm{L}$ and the ratio of cellulase to pectinase 1:2, 1:3, 1:1, 2:1, 3:1 on the extraction rate and light transmittance of Hibiscus Sabdariffa reducing sugar were studied.

Effect of enzymatic hydrolysis time of cellulase and pectinase on enzymatic hydrolysis of Hibiscus Sabdariffa was determined as follows, under the conditions of enzymolysis temperature $50^{\circ} \mathrm{C}$, $\mathrm{pH} 4.5$, the total addition amount of cellulase and pectinase was $40 \mu \mathrm{L}$, the ratio of Pectinase to cellulase was $1: 3$, the extraction rate and transmittance of Hibiscus Sabdariffa reducing sugar were studied at $0,2 \mathrm{~h}, 4 \mathrm{~h}, 6 \mathrm{~h}, 8 \mathrm{~h}, 10 \mathrm{~h}$.

Effect of enzymatic hydrolysis temperature of cellulase and pectinase complex enzyme on enzymatic hydrolysis effect of Hibiscus Sabdariffa was determined as follows, under the condition of $\mathrm{pH} 4.5$, the total amount of cellulase and pectinase complex enzyme was $40 \mu \mathrm{L}$, the ratio of pectinase and cellulase was 1:3, and the enzymolysis time was $6 \mathrm{~h}$. The extraction rate and transmittance of Hibiscus Sabdariffa reducing sugar were studied at $35^{\circ} \mathrm{C}, 40^{\circ} \mathrm{C}, 45^{\circ} \mathrm{C}, 50^{\circ} \mathrm{C}, 55^{\circ} \mathrm{C}$ and $60^{\circ} \mathrm{C}$.

\subsection{Optimization of enzymatic hydrolysis process by response surface methodology}

According to box-Behnken's central composite experiment design principle and the results of single factor experiment, the experiment was designed with the ratio of complex enzyme, enzymolysis time, enzymolysis temperature and compound enzyme dosage as independent variables and the extraction rate of Hibiscus Sabdariffa reducing sugar as response value. The response surface analysis method of 3 factors (factorA-Compound enzyme dosage, factor B-Compound enzyme ratio, and factor C-Enzymolysis time) and 3 levels was used (as shown in Table 1 notes). The design of test factors and levels is. Combined with the experimental results, regression analysis was carried out to investigate the effects of complex enzyme dosage, compound enzyme ratio and enzymatic hydrolysis time on the extraction rate of Hibiscus Sabdariffa reducing sugar. Response surface methodology was used to optimize the extraction conditions (Li et al., 2016). With the experiment conducted in a random order, the response values were analyzed by design expert v8.0 software, and the response surface analysis chart and variance analysis table were given.

\subsection{Verification test}

Under the optimal extraction conditions of reducing sugar from Hibiscus Sabdariffa by cellulase and pectinase complex enzyme, three groups of validation tests were carried out in parallel.

\subsection{Statistical analysis}

Quantitative data are represented as mean $\pm \mathrm{SD}$. To evaluate the differences at $95 \%$ confidence level ( $\mathrm{p} \leq 0.05$ ), a one-way analysis of variance (ANOVA) followed by Tukey's test was performed using Minitab 16 statistical software (Minitab Inc., Pennsylvania).

\section{Results and discussion}

\subsection{Determination of reducing sugar and light transmittance}

In the experiment of reducing sugar determination, the standard curve method is needed for quantitative analysis. The standard curve is shown in Figure 2: $\mathrm{A}=8.7904 \mathrm{c}+0.0052$ ( $\mathrm{a}$ is the absorbance value, $\mathrm{C}$ is the concentration of glucose solution). The linear correlation coefficient $\mathrm{R}^{2}=0.9991$, which meets the requirements of standard curve. The results showed that there 
Table 1. Box-Behnken experimental design and results for response surface analysis.

\begin{tabular}{ccccc}
\hline $\begin{array}{c}\text { Experiment } \\
\text { numbers }\end{array}$ & $\begin{array}{c}\text { Compound enzyme } \\
\text { dosage }(\mathrm{A})\end{array}$ & $\begin{array}{c}\text { Complex enzyme ratio } \\
\text { (cellulase: pectinase) }(\mathrm{B})\end{array}$ & $\begin{array}{c}\text { Enzymolysis time } \\
(\mathrm{C})\end{array}$ & $\begin{array}{c}\text { Concentration of reducing sugar } \\
(\mathrm{R} 1 \mathrm{mg} / \mathrm{ml})\end{array}$ \\
\hline 1 & 1 & 0 & 1 & 1.62483 \\
2 & 0 & 0 & 0 & 3.31251 \\
3 & 1 & -1 & 0 & 2.1218 \\
4 & -1 & 1 & 0 & 2.97699 \\
5 & 0 & 0 & -1 & 3.22926 \\
6 & 0 & 1 & 1 & 3.23936 \\
7 & 0 & -1 & 0 & 2.23784 \\
8 & 1 & 1 & 1 & 2.18991 \\
9 & -1 & 0 & -1 & 1.84935 \\
10 & 0 & -1 & 1 & 3.22674 \\
11 & 0 & 1 & -1 & 2.39677 \\
12 & -1 & 0 & 0 & 3.29485 \\
13 & -1 & -1 & 0 & 2.67679 \\
14 & 0 & 0 & 0 & 3.21161 \\
15 & 0 & 0 & -1 & 3.24188 \\
17 & 1 & 0 & 0 & 2.7222 \\
\hline
\end{tabular}

For factor A, factor coding $-1=30 \mu \mathrm{L}, 0=40 \mu \mathrm{L}, 1=50 \mu \mathrm{L}$; for factor $\mathrm{B}$, factor coding $-1=2: 1,0=1: 1,1=1: 2$; for factor $\mathrm{C}$, factor coding $-1=2 \mathrm{~h}, 0=4 \mathrm{~h}, 1=6 \mathrm{~h}$.

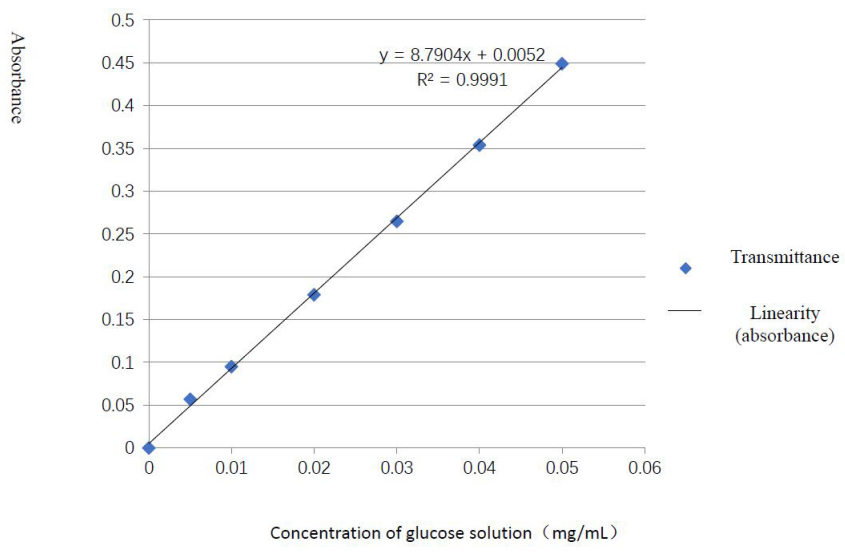

Figure 2. Standard curve of glucose concentration-absorbance. The standard curve of glucose concentration absorbance was drawn: $\mathrm{A}=8.7904 \mathrm{x}+0.0052$ ( $\mathrm{a}$ is the absorbance value, $\mathrm{C}$ is the concentration of glucose solution).

was a good linear relationship between glucose and absorbance in the range of $0.00-0.05 \mathrm{mg} / \mathrm{ml}$.

\subsection{Effect of various factors on enzymatic hydrolysis of cellulase and pectinase compound enzyme}

\section{Effect of pectinase addition on enzymatic hydrolysis}

Under different dosage of pectinase, the concentration of reducing sugar and light transmittance of Hibiscus Sabdariffa were determined to study the effect of pectinase dosage on enzymatic hydrolysis. With the increase of pectinase dosage, the extraction rate of reducing sugar in Hibiscus Sabdariffa extract increases continuously. When it reaches $40 \mu \mathrm{L}$, the extraction rate of reducing sugar begins to decrease; between 0 and $40 \mu \mathrm{L}$, the transmittance increases continuously, and after $40 \mu \mathrm{L}$, the light transmittance begins to decrease. When the amount of pectinase was $40 \mu \mathrm{L}$, the concentration of reducing sugar was the highest, reaching $1.075 \mathrm{mg} / \mathrm{ml}$.

\section{Effect of cellulase addition on enzymatic hydrolysis}

In order to study the effect of pectinase dosage on the enzymatic hydrolysis of Hibiscus Sabdariffa, the concentration of reducing sugar and light transmittance of reducing sugar were measured with different pectinase dosage (Liao et al., 2015).

It can be seen from Figure that when the dosage of cellulase is increased from $0 \mu \mathrm{L}$ to $35 \mu \mathrm{L}$, the extraction rate and light transmittance of the extraction solution continue to increase. However, when the dosage exceeds $35 \mu \mathrm{L}$, the concentration of reducing sugar begins to decrease, and the increase of light transmittance tends to be gentle. At this time, the concentration of reducing sugar in the extract is $0.392 \mathrm{mg} / \mathrm{ml}$.

The results showed that cellulase could obviously improve the light transmittance of the extract, which indicated that the extract of Hibiscus Sabdariffa contained a certain amount of fiber and hemifiber. With the increase of the dosage of cellulase, the content of soluble solids in the extract also increased. On the one hand, some fibers were degraded into soluble substances by cellulase, on the other hand, it was due to the addition of cellulase protein.

Effect of cellulase and pectinase compound enzyme addition on enzymatic hydrolysis

The concentration of reducing sugar and light transmittance of Hibiscus Sabdariffa were measured when adding different doses of pectinase and cellulase complex enzyme, so as to study the effect of complex enzyme on enzymatic hydrolysis (Ma et al., 
2018). As shown in Figure 3, when the ratio of cellulase to pectinase was 1:1, with the increase of the amount of cellulase and pectinase complex enzyme, the concentration of reducing sugar in Hibiscus Sabdariffa enzymatic hydrolysate first increased and then decreased slightly, and the amount of compound enzyme was 40 in the enzymatic reaction, when the substrate concentration is far greater than the enzyme concentration, the reaction speed will be accelerated with the increase of enzyme dosage; when the substrate is fully combined with the enzyme, the reaction speed will not change with the increase of enzyme dosage; however, with the increase of enzymatic hydrolysis products, it will inhibit the enzymatic hydrolysis reaction. The extraction of reducing sugars increased firstly and then decreased.

The results showed that the light transmittance of Hibiscus Sabdariffa enzymatic hydrolysate decreased significantly at the beginning stage, and tended to be flat at the later stage; with the increase of the complex enzyme dosage from $10 \mu \mathrm{L}$ to $40 \mu \mathrm{L}$, the light transmittance of the extract increased continuously, and reached the maximum at $40 \mathrm{~mL} \mu \mathrm{L}$. then, with the increase of the complex enzyme dosage, the light transmittance of the extract decreased, which may be due to the increase of the turbidity of the extraction solution, so that the light transmittance decreased Down. Therefore, $40 \mu \mathrm{l}$ of cellulase and pectinase compound enzyme can achieve better enzymatic hydrolysis effect. At the same time, the results showed that the extraction efficiency of pectinase mixed with cellulase was higher than that of single enzyme, and the extraction effect of pectinase was better than that of cellulase.
Effect of the ratio of cellulase to pectinase on enzymatic hydrolysis

The concentration of reducing sugar and light transmittance of Hibiscus Sabdariffa were determined under different ratio of pectinase and cellulase, so as to study the effect of the ratio of pectinase and cellulase on enzymatic hydrolysis. As shown in Figure 3 , under the condition of $40 \mu \mathrm{L}$ of cellulase and pectinase complex enzyme, when the ratio of cellulase to pectinase was 1:3, the concentration of reducing sugar from Hibiscus Sabdariffa was the highest, reaching $2.808 \mathrm{mg} / \mathrm{ml}$; the light transmittance of enzymatic hydrolysate of Hibiscus Sabdariffa first decreased and then increased, and with the increase of the ratio of cellulase and pectinase, the change of light transmittance tended to be stable. Therefore, when the ratio of cellulase to pectinase is $1: 3$, the higher concentration of reducing sugar can be obtained.

\section{Effect of enzymatic hydrolysis time of pectinase and cellulase composite enzyme on enzymatic hydrolysis effect}

Under different enzymolysis time, the concentration of reducing sugar and light transmittance of Hibiscus Sabdariffa were measured, so as to study the effect of enzymolysis time on the enzymolysis effect of complex enzyme. As shown in Figure 3, with the extension of enzymolysis time, the concentration of reducing sugar from Hibiscus Sabdariffa rises continuously, and it has a downward trend when the enzymolysis time is $8 \mathrm{~h}$. When the enzymolysis time is $6 \mathrm{~h}$, the concentration of reducing sugar is the highest; the transmittance reaches the maximum value between 2-6 h. The reason may be that with the extension of time, the components in Hibiscus Sabdariffa reducing sugar lose their
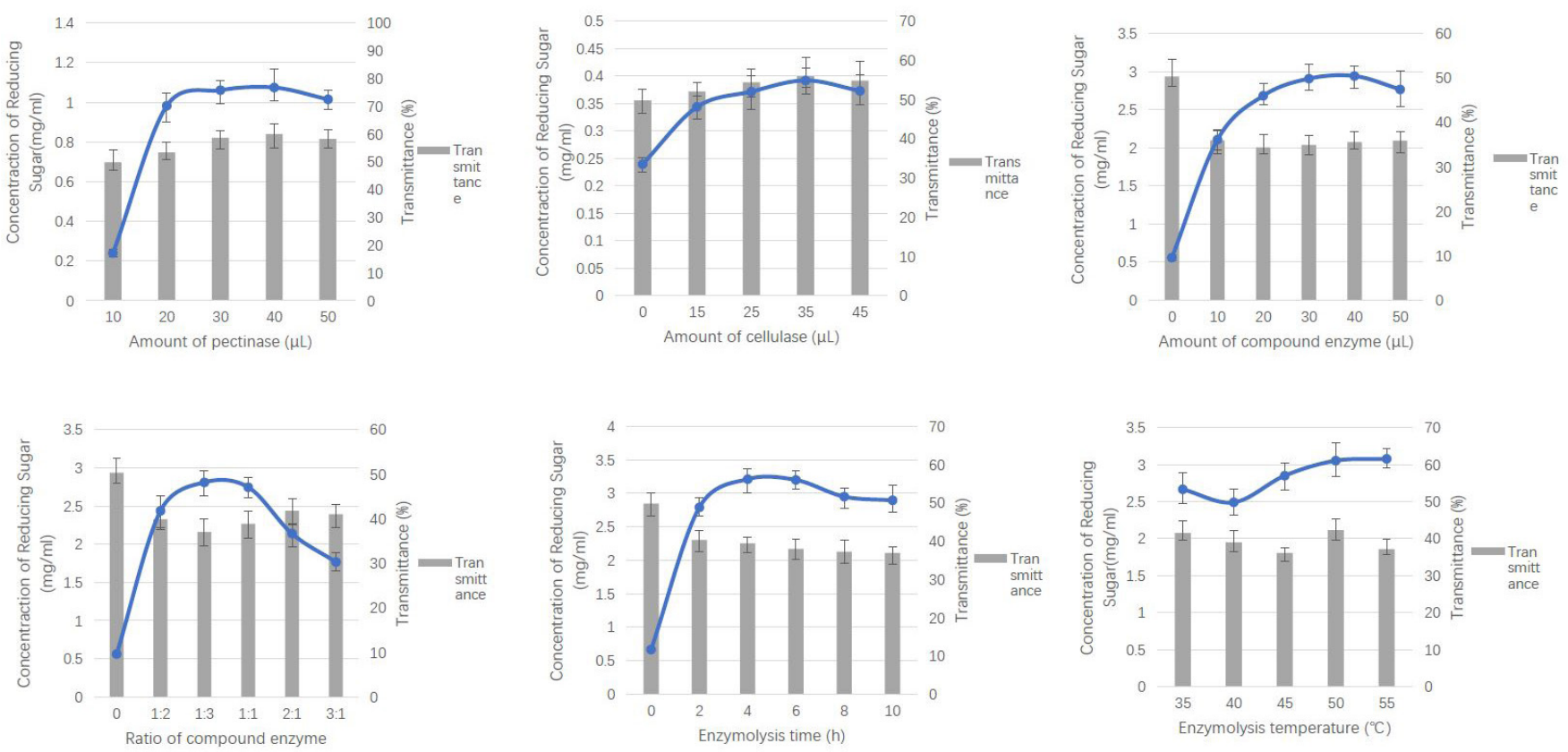

Figure 3. Effect of various factors on enzymatic hydrolysis of cellulase and pectinase compound enzyme. The effect of pectinase addition, cellulase addition, cellulase and pectinase compound enzyme addition, the ratio of cellulase to pectinase, enzymatic hydrolysis time of pectinase and cellulase composite enzyme, hydrolysis temperature of cellulase and pectinase composite enzyme on enzymatic hydrolysis was determined, and the results show that among them, the amount of compound enzyme, the proportion of compound enzyme and the time of enzymatic hydrolysis have the most significant effect on the enzymatic hydrolysis effect, including the influence of various factors on the reducing sugar concentration and the light transmittance of the enzymatic hydrolysis solution. 
activity. Through the above experiments, it can be seen that the enzymatic hydrolysis effect of pectinase and cellulase composite enzyme is better than that of pectinase or cellulase alone, which can obtain higher the concentration of reducing sugar.

\section{Effect of hydrolysis temperature of cellulase and pectinase} composite enzyme on enzymatic hydrolysis effect

In order to study the effect of enzymolysis temperature on the enzymatic hydrolysis of Hibiscus Sabdariffa, the concentration of reducing sugar and light transmittance of Hibiscus Sabdariffa were measured under different enzymolysis temperature (Gonzalez-Palomares et al., 2009). Under the condition of $\mathrm{pH} 4.5$, the total amount of cellulase and pectinase complex enzyme was $40 \mu \mathrm{L}$, the ratio of Pectinase to cellulase was 1:3, the enzymolysis time was $6 \mathrm{~h}$, the extraction rate and transmittance of reducing sugar were studied at $35^{\circ} \mathrm{C}, 40^{\circ} \mathrm{C}, 45^{\circ} \mathrm{C}, 50^{\circ} \mathrm{C}, 55^{\circ} \mathrm{C}$ and $60^{\circ} \mathrm{C}$.

As shown in Figure 3, with the increase of enzymolysis temperature, the extraction of reducing sugar in Hibiscus Sabdariffa enzymatic hydrolysate firstly decreased and then increased, and the rising trend tended to be gentle at the enzymolysis temperature of $45^{\circ} \mathrm{C}$; the transmittance showed an increasing trend between $45^{\circ} \mathrm{C}$ and $50^{\circ} \mathrm{C}$, and showed a downward trend after the enzymolysis temperature of $50{ }^{\circ} \mathrm{C}$. Considering the effect of energy saving and enzymatic hydrolysis, $45^{\circ} \mathrm{C}$ was selected as the temperature condition of enzymatic hydrolysis.

\subsection{Optimization of complex enzyme system for enzymatic hydrolysis of Hibiscus Sabdariffa by Response Surface Methodology}

According to the results of single factor test, according to the box Behnken design method, taking the amount of complex enzyme, the proportion of complex enzyme and the time of enzymatic hydrolysis as variables (Cai et al., 2019), the concentration of reducing sugar as the response value, and the variable level represented by $-1,0,1$ respectively, repeated 5 times at the central point, a total of 17 times (Li et al., 2021).
The experimental results are shown in Table 1, and design expert 8.0 was applied The results were analyzed by multiple regression (Marín et al., 2019).

The software was used to conduct multiple regression analysis on the experimental data. The quadratic regression equation was established with reducing sugar extraction rate (R1) as dependent variable, compound enzyme addition amount (a), compound enzyme proportion (b) and enzymolysis time (c) as independent variables: $\mathrm{R} 1=3.26-0.29 \mathrm{~A}+0.091 \mathrm{~B}-$ $0.42 \mathrm{C}-0.058 \mathrm{AB}+0.14 \mathrm{AC}-0.011 \mathrm{BC}-0.51 \mathrm{~A}^{2}-0.26 \mathrm{~B}^{2}-0.28 \mathrm{C}^{2}$

Design expert 8.0 was used to analyze the variance of the test results in Table 1. The results are shown in Table 2.

It can be seen that $\mathrm{f}=148.02>\mathrm{f} 0.01(9,4)=14.66$, $\mathrm{p}<0.0001$, indicating that the model equation (1) is extremely significant; $F=6.00<f 0.05(9,3)=8.81$, and the mismatch term $\mathrm{p}=0.0875>0.05$, the difference is not significant. The positive coefficient of determination $\mathrm{R}^{2}$ adj $=0.9881$, that is, the model can explain $98.81 \%$, and $0.19 \%$ variation can not be explained by the model; the model determination coefficient $\mathrm{R}^{2}=0.9948$, the correlation between the predicted value and the actual value is good, and this model can be used to analyze and predict the reducing sugar content of Hibiscus Sabdariffa.

From the significance test, it can be seen that the $\mathrm{p}$ value corresponding to $\mathrm{A}^{2}, \mathrm{~B}^{2}$ and $\mathrm{C}^{2}$ is less than 0.01 , and the influence is extremely significant; the $p$ value corresponding to $A B$ is less than 0.05, which has significant influence; a, B, C, AC, BC have no significant influence on the results. According to $\mathrm{F}$ test, the contribution rate of each factor was enzymolysis time $>$ compound enzyme dosage $>$ compound enzyme proportion.

\subsection{Interaction analysis of complex enzymatic hydrolysis}

The response surface and contour lines of the interaction among the three factors, such as the amount of complex enzyme, the ratio of complex enzyme and enzymatic hydrolysis time, are shown in Figure 4. The contour shape in the figure can reflect the

Table 2. ANOVA for Response Surface Quadratic Model.

\begin{tabular}{|c|c|c|c|c|c|c|}
\hline Source & Sum of Squares & Df & Mean Square & F Value & $\mathrm{p}$-value & Significance \\
\hline Model & 4.11 & 9 & 0.46 & 148.02 & $<0.0001$ & $* *$ \\
\hline A-Amount of compound enzyme & 0.68 & 1 & 0.68 & 221.96 & $<0.0001$ & ** \\
\hline B-Complex enzyme ratio & 0.067 & 1 & 0.067 & 21.61 & 0.0023 & $* *$ \\
\hline C- Enzymolysis time & 1.41 & 1 & 1.41 & 459.12 & $<0.0001$ & ** \\
\hline$A B$ & 0.013 & 1 & 0.013 & 4.37 & 0.0749 & \\
\hline $\mathrm{AC}$ & 0.075 & 1 & 0.075 & 24.37 & 0.0017 & $* *$ \\
\hline BC & 0.0004772 & 1 & 0.0004772 & 0.15 & 0.7057 & \\
\hline $\mathbf{A}^{2}$ & 1.08 & 1 & 1.08 & 351.18 & $<0.0001$ & $* *$ \\
\hline $\mathrm{B}^{2}$ & 0.28 & 1 & 0.28 & 90.32 & $<0.0001$ & ** \\
\hline $\mathrm{C}^{2}$ & 0.32 & 1 & 0.32 & 103.84 & $<0.0001$ & $* *$ \\
\hline Residual & 0.022 & 7 & 0.003082 & & & \\
\hline Lack of Fit & 0.017 & 3 & 0.005572 & 4.59 & 0.0875 & \\
\hline Pure Error & 0.004855 & 4 & 0.001214 & & & \\
\hline Cor Total & 4.13 & 16 & & & & \\
\hline $\mathbf{R}^{2}$ & 0.9948 & & & & & \\
\hline $\mathbf{R}^{2} \mathbf{a d j}$ & 0.9881 & & & & & \\
\hline
\end{tabular}

**Extremely significant difference $(\mathrm{p}<0.01)$. 

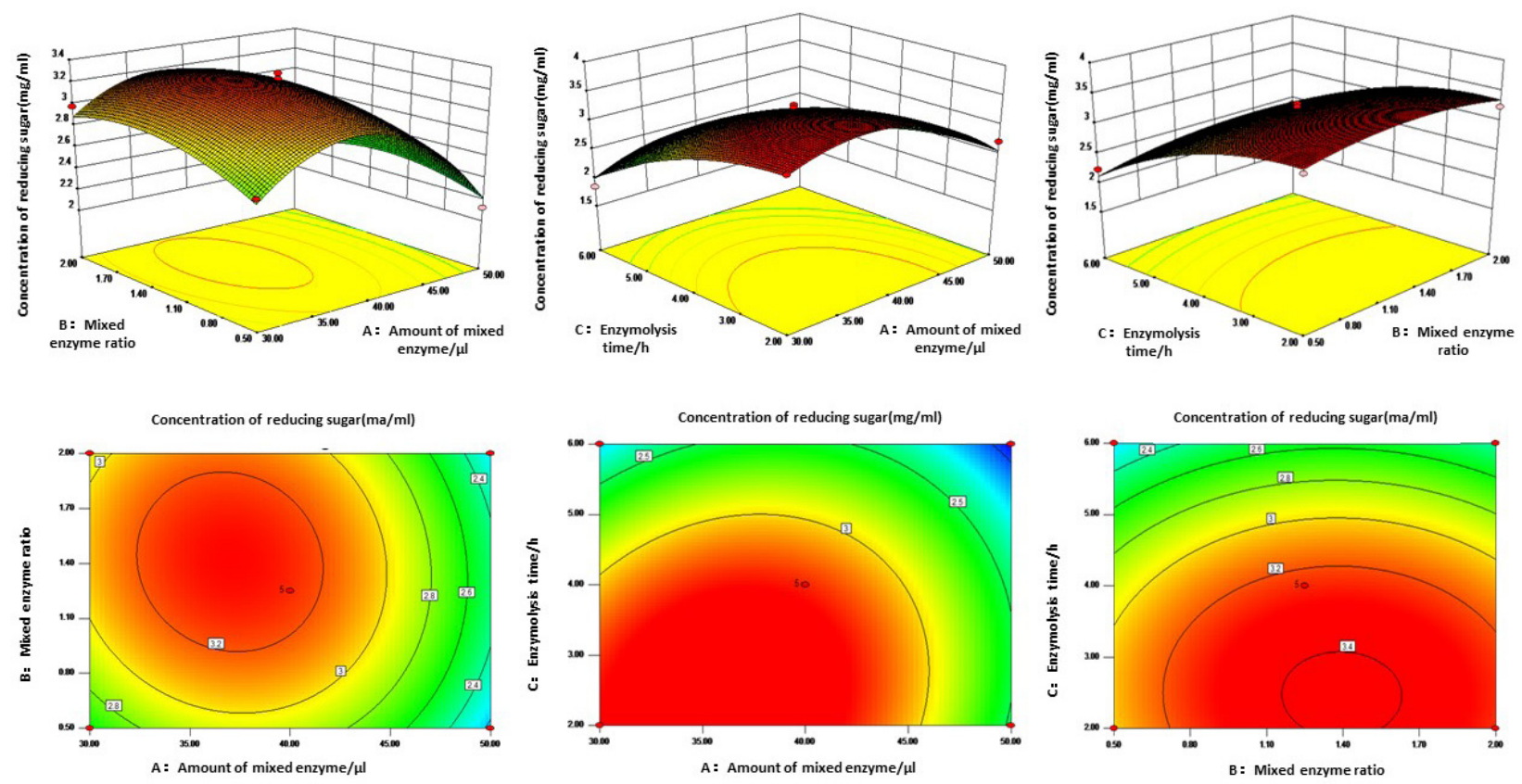

Figure 4. Response surface and contour plot for composite enzyme ratio and time on reducing sugar content and enzyme additive contents. The figure shows the response surface and contour of the interaction among the three factors of compound enzyme dosage, compound enzyme ratio and enzymolysis time. The contour shape in the figure can reflect the size of the interaction, when it is oval, it means that the interaction is significant, and the interaction between the amount of compound enzyme and Enzymolysis time is the most significant.

interaction size (Chen et al., 2020b). When it is oval, it indicates that the interaction is significant, while the circle indicates that the interaction is not significant (Liu et al., 2019).

As Figure 4 showed, when the enzymolysis time is $4 \mathrm{~h}$, the extraction rate of Hibiscus Sabdariffa reducing sugar increases first and then decreases with the increase of the complex enzyme proportion; when the complex enzyme dosage is fixed, the extraction rate of Hibiscus Sabdariffa reducing sugar first increases and then decreases with the increase of complex enzyme proportion.

When the ratio of complex enzyme is 1:1, the concentration of reducing sugar increases first and then decreases with the increase of the proportion of cellulase in the composite enzyme with the addition amount of complex enzyme; the concentration of reducing sugar from Hibiscus Sabdariffa decreases with the extension of enzymatic hydrolysis time with the addition of complex enzyme.

When the enzyme dosage is $40 \mu \mathrm{L}$ and the hydrolysis time is fixed, the concentration of reducing sugar increases first and then decreases with the increase of the proportion of Pectinase in the composite enzyme, and the concentration of reducing sugar from Hibiscus Sabdariffa decreases with the increase of the proportion of complex enzyme.

\subsection{Simulation and verification of optimal enzymatic hydrolysis conditions by response surface analysis}

The regression equation is solved by design expert system, and a group of optimization schemes are obtained. The optimal conditions of enzymatic hydrolysis were as follows: $0.011 \mathrm{~g} / \mathrm{kg}$ of pectinase and cellulase, 1.36:1 of compound enzyme ratio, $2.09 \mathrm{~h}$ of enzymatic hydrolysis time, and the concentration of reducing sugar of Hibiscus Sabdariffa was $3.56 \mathrm{mg} / \mathrm{ml}$. Combined with the actual experiment, under the conditions of compound enzyme ratio of $1.36: 1$, addition amount of $0.011 \mathrm{~g} / \mathrm{kg}$, enzymolysis time of $135 \mathrm{~min}$ and enzymolysis temperature of $45^{\circ} \mathrm{C}$, the extraction rate of Hibiscus Sabdariffa reducing sugar reached $3.54 \pm 0.1 \%$, which showed that the predicted value of the model was in good agreement with the actual value of the experiment, which had the value of guiding the actual production.

\section{Conclusion}

The results showed that the enzymatic hydrolysis process of Hibiscus Sabdariffa was optimized by response surface analysis. The main factors affecting the enzymatic hydrolysis of Hibiscus Sabdariffa were enzymatic hydrolysis time, and the secondary factors were the amount of complex enzyme and the proportion of complex enzyme. The results showed that the extraction efficiency of pectinase mixed with cellulase was higher than that of single enzyme, and the extraction effect of pectinase was better than that of cellulase. The optimum conditions for enzymatic hydrolysis of Hibiscus Sabdariffa were as follows: the addition of pectinase and cellulase was $0.011 \mathrm{~g} / \mathrm{kg}$, the ratio of mixed enzyme was 1.36:1, the enzymolysis time was $2.09 \mathrm{~h}$, and the concentration of reducing sugar from Hibiscus Sabdariffa was 3.565. In this experiment, pectinase and cellulase were used in combination, which was conducive to the retention of nutrients and material saving. The results of this study have a guiding role in the development and utilization of enzymatic hydrolysis technology of Hibiscus Sabdariffa. 


\section{Acknowledgements}

This work was supported by the (Key)Project of Department of Education of Guangdong Province (No2018ktscx270) and Youth Innovation Talent Project of regular college in Guangdong Province (2018kqncx306).

\section{References}

Archaina, D., Vasile, F., Jiménez-Guzmán, J., Alamilla-Beltrán, L., \& Schebor, C. (2019). Physical and functional properties of Hibiscus Sabdariffa (Hibiscus sabdariffa L. ) extract spray dried with maltodextrin-gum arabic mixtures. Journal of Food Processing and Preservation, 43(9), e14065. http://dx.doi.org/10.1111/jfpp.14065.

Arenas, K. S. L., Victoria, M. T. C., Mendoza, M. G. V., Vera, C. M., \& Sosa, I. A. (2016). Effect of agitated bed drying on the retention of phenolic compounds, anthocyanins and antioxidant activity of Hibiscus Sabdariffa (Hibiscus sabdariffa L.). International Journal of Food Science \& Technology, 6(51), 1457-1464. http://dx.doi. org/10.1111/ijfs.13118.

Cai, L. L., Chen, B. H., Yi, F. L., \& Zou, S. S. (2019). Optimization of extraction of polysaccharide from dandelion root by response surface methodology: structural characterization and antioxidant activity. International Journal of Biological Macromolecules, 140, 907-919. http://dx.doi.org/10.1016/j.ijbiomac.2019.08.161. PMid:31437509.

Carvajal-Zarrabal, O., Barradas-Dermitz, D. M., Orta-Flores, Z., Hayward-Jones, P. M., Nolasco-Hipólito, C., Aguilar-Uscanga, M. G., Miranda-Medina, A., \& Bujang, K. B. (2012). Hibiscus sabdariffa L., roselle calyx, from ethnobotany to pharmacology. Journal of Experimental Pharmacology, 4, 25-39. http://dx.doi.org/10.2147/ JEP.S27974.

Chen, L., Long, R., Huang, G., \& Huang, H. (2020a). Extraction and antioxidant activities in vivo of pumpkin polysaccharide. Industrial Crops and Products, 146, 112199. http://dx.doi.org/10.1016/j. indcrop.2020.112199.

Chen, L., Wei, Y., Shi, M., Li, Z. Q., \& Zhang, S.-H. (2020b). Statistical optimization of a cellulase from Aspergillus glaucus CCHA for hydrolyzing corn and rice straw by RSM to enhance yield of reducing sugar. Biotechnology Letters, 42(4), 583-595. http://dx.doi.org/10.1007/ s10529-020-02804-5. PMid:31980972.

Dhar, P., Kar, C. S., Ojha, D., Pandey, S. K., \& Mitra, J. (2015). Chemistry, phytotechnology, pharmacology and nutraceutical functions of kenaf (Hibiscus cannabinus L.) and Hibiscus Sabdariffa (Hibiscus sabdariffa L.) seed oil: an overview. Industrial Crops and Products, 77, 323-332. http://dx.doi.org/10.1016/j.indcrop.2015.08.064.

Gonzalez-Palomares, S., Estarrón-Espinosa, M., Gómez-Leyva, J. F., \& Andrade-González, I. (2009). Effect of the temperature on the spray drying of roselle extracts (Hibiscus sabdariffa L.). Plant Foods for Human Nutrition (Dordrecht, Netherlands), 64(1), 62-67. http:// dx.doi.org/10.1007/s11130-008-0103-y. PMid:19082732.

Li, C. J., Ju, J., Xie, Y. F., Yu, H., Guo, Y. H., Yao, W. R., \& Qian, H. (2021). Effects of interactions between polygalacturonase and pesticide residues during enzymatic hydrolysis on the yield of apple juice. LWT, 147, 111562. http://dx.doi.org/10.1016/j.lwt.2021.111562.

Li, H., Ke, H. X., Li, F. J., Dong, H. J., He, J. X., Zhang, J. D., \& Yang, B. (2016). Optimization of aqueous two-phase extraction of polysaccharide from schisandra chinensis using response surface methodology with box-behnken design. Journal of Chinese Medicinal Materials, 39(3), 593-597. PMid:30091354.

Li, J. B., Zhang, H. Y., Lu, M. S., \& Han, L. J. (2019). Comparison and intrinsic correlation analysis based on composition, microstructure and enzymatic hydrolysis of corn stover after different types of pretreatments. Bioresource Technology, 293, 122016. http://dx.doi. org/10.1016/j.biortech.2019.122016. PMid:31473375.

Liao, J., Yan, F. Y., Mo, L. X., Wang, T. S., Ya, Y., Fan, Y. G., Huang, F., Lin, B., \& Tang, L. (2015). Evaluation of uncertainty in determination of reducing sugar content in sugarcane. Agricultural Biotechnology, 4(4), 72-76. 10.19759/j.cnki.2164-4993.2015.04.018.

Liu, D. M., Liu, Y.X., Wang, D. M., Liang, P. X., Pan, L. P., Chen, J. P., \& Qin, J. H. (2019). Optimization of extraction process of anthocyanins from selenium-enriched purple potato by response surface methodology. Agricultural Biotechnology, 8(4), 173-177. 10.19759/j.cnki.2164-4993.2019.04.040.

Ma, S. H., Neilson, A., Lahne, J., Peck, G., O’Keefe, S., Hurley, E. K., Sandbrook, A., \& Stewart, A. (2018). Juice clarification with pectinase reduces yeast assimilable nitrogen in apple juice without affecting the polyphenol composition in cider. Journal of Food Science, 83(11), 2772-2781. http://dx.doi.org/10.1111/1750-3841.14367. PMid:30347443.

Magro, L. D., De Moura, K. S., Backes, B. E., De Menezes, E. W. Benvenutti, E. V., Nicolodi, S., Klein, M. P., Fernandez-Lafuente, R., \& Rodrigues, R. C. (2019). Immobilization of pectinase on chitosanmagnetic particles: influence of particle preparation protocol on enzyme properties for fruit juice clarification. Biotechnology Reports (Amsterdam, Netherlands), 24, e00373. http://dx.doi.org/10.1016/j. btre.2019.e00373.PMid:31516853.

Magro, L. M., Silveira, V. C. C., de Menezes, E. W., Benvenutti, E. V., Nicolodi, S., Hertz, P. F., Klein, M. P., \& Rodrigues, R. C.. (2018). Magnetic biocatalysts of pectinase and cellulase: synthesis and characterization of two preparations for application in grape juice clarification. International Journal of Biological Macromolecules, 115, 35-44. http://dx.doi.org/10.1016/j.ijbiomac.2018.04.028.

Marín, M., Artola, A., \& Sánchez, A. (2019). Optimization of downstream for cellulases produced under solid-state fermentation of coffee husk. Waste and Biomass Valorization, 10(10), 2761-2772. http://dx.doi.org/10.1007/s12649-018-0327-5.

Riaz, G., \& Chopra, R. (2018). A review on phytochemistry and therapeutic uses of Hibiscus sabdariffa L. Biomedicine and Pharmacotherapy, 102, 575-586. http://dx.doi.org/10.1016/j.biopha.2018.03.023.

Salem, M. A., Zayed, A., Beshay, M. E., Mesih, M. M. A., Khayal, R. F. B., George, F. A., \& Ezzat, S. M. (2021) Hibiscus sabdariffa L.: phytoconstituents, nutritive, and pharmacological applications. Advances in Traditional Medicine, 1-11. 10.1007/s13596-020-00542-7.

Uddin Pk, M. M. M., Islam, M. S., Pervin, R., Dutta, S., Talukder, R. I., \& Rahman, M. (2019). Optimization of extraction of antioxidant polysaccharide from Pleurotus ostreatus (Jacq.) P. Kumm and its cytotoxic activity against murine lymphoid cancer cell line. PLoS One, 14(1), e0209371. http://dx.doi.org/10.1371/journal.pone.0209371. PMid:30605465.

Zhao, X., \& Dong, C. (2016). Extracting xylooligosaccharides in wheat bran by screening and cellulase assisted enzymatic hydrolysis. International Journal of Biological Macromolecules, 92, 748-752. http://dx.doi.org/10.1016/j.ijbiomac.2016.07.037. PMid:27422041.

Zhen, J., Villani, T. S., Guo, Y., Qi, Y., Chin, K., Pan, M., Ho, C., Simon, J. E., \& Wu, Q. (2016). Phytochemistry, antioxidant capacity, total phenolic content and anti-inflammatory activity of Hibiscus sabdariffa leaves. Food Chemistry, 190, 673-680. http://dx.doi.org/10.1016/j. foodchem.2015.06.006. PMid:26213025.

Zhou, L., Pan, F., Liu, Y., Kang, Z., Zeng, S., \& Nie, Y. (2020). Study on the regularity of cellulose degradation in ionic liquids. Journal of Molecular Liquids, 308, 113153. http://dx.doi.org/10.1016/j. molliq.2020.113153. 